\title{
Spatial distribution of halophytes and environment factors in salt marshes along the eastern Yellow Sea
}

\author{
Jaesang Chung ${ }^{1+}$, Jae Hyun Kim²,3† and Eun Ju Lee ${ }^{4^{*}}$
}

\begin{abstract}
Background: Salt marshes provide a variety of ecosystem services; however, they are vulnerable to human activity, water level fluctuations, and climate change. Analyses of the relationships between plant communities and environmental conditions in salt marshes are expected to provide useful information for the prediction of changes during climate change. In this study, relationships between the current vegetation structure and environmental factors were evaluated in the tidal flat at the southern tip of Ganghwa, Korea, where salt marshes are well-developed.

Results: The vegetation structure in Ganghwa salt marshes was divided into three groups by cluster analysis: group A, dominated by Phragmites communis; group B, dominated by Suaeda japonica; and group C, dominated by other taxa. As determined by PERMANOVA, the groups showed significant differences with respect to altitude, soil moisture, soil organic matter, salinity, sand, clay, and silt ratios. A canonical correspondence analysis based on the percent cover of each species in the quadrats showed that the proportion of sand increased as the altitude increased and S. japonica appeared in soil with a relatively high silt proportion, while P. communis was distributed in soil with low salinity.

Conclusions: The distributions of three halophyte groups differed depending on the altitude, soil moisture, salinity, and soil organic matter, sand, silt, and clay contents. Pioneer species, such as S. japonica, appeared in soil with a relatively high silt content. The $P$. communis community survived under a wider range of soil textures than previously reported in the literature; the species was distributed in soils with relatively low salinity, with a range expansion toward the sea in areas with freshwater influx. The observed spatial distribution patterns may provide a basis for conservation under declining salt marshes.
\end{abstract}

Keywords: Phragmites communis, Suaeda japonica, Pioneer species, Spatial distribution

\footnotetext{
* Correspondence: ejlee@snu.ac.kr

${ }^{\dagger}$ Jaesang Chung and Jae Hyun Kim contributed equally to this work.

${ }^{4}$ School of Biological Sciences, Seoul National University, Seoul 08826,

Republic of Korea

Full list of author information is available at the end of the article
}

(c) The Author(s). 2021 Open Access This article is licensed under a Creative Commons Attribution 4.0 International License, which permits use, sharing, adaptation, distribution and reproduction in any medium or format, as long as you give appropriate credit to the original author(s) and the source, provide a link to the Creative Commons licence, and indicate if changes were made. The images or other third party material in this article are included in the article's Creative Commons licence, unless indicated otherwise in a credit line to the material. If material is not included in the article's Creative Commons licence and your intended use is not permitted by statutory regulation or exceeds the permitted use, you will need to obtain permission directly from the copyright holder. To view a copy of this licence, visit http://creativecommons.org/licenses/by/4.0/. 


\section{Background}

Coastal salt marshes are ecosystems that connect terrestrial and marine ecosystems. Halophytes in salt marshes tend to have a zonal distribution along an altitudinal gradient (Bang et al. 2018; Santelmann et al. 2019). This is because the altitude determines the inundation frequency (Santelmann et al. 2019). Inundation places great stress on plants, which are typically not tolerant to salinity. Thus, the distribution of halophytes is determined by the ability of taxa to withstand an oxygen-free, high-saline environment by excreting or avoiding salt (Colmer and Flowers 2008; Parida and Das 2005). Other factors determining halophyte distributions include soil texture (Brereton 1971; Ihm et al. 2007), salinity (Silvestri et al. 2005), herbivory (Olff et al. 1997), and interspecific competition (Bertness and Ellison 1987). In general, pioneer species are highly resistant to stress.

The Yellow Sea has well-developed salt marshes, providing important wetland habitats for diverse wildlife in East Asia (Ministry of Oceans and Fisheries 2020). However, factors such as development projects and industrial effluent (Newton et al. 2020) have resulted in declining salt marshes. For example, from the 1950s to 2000s, salt marshes along the Yellow Sea have decreased by $51.4 \%$ as a result of land reclamation. Additionally, $65.6 \%$ of the salt marshes in South Korea have disappeared (Murray et al. 2014). As of 2018, Ganghwa has vast tidal flats covering $256.1 \mathrm{~km}^{2}$, accounting for about $10 \%$ of the tidal flats in Korea (Ministry of Oceans and
Fisheries 2020); however, development projects in the 1990s altered the physical structure of the salt marsh near Ganghwa Island, resulting in extensive die-off of Suaeda japonica (Y.-K. Lee et al. 2014).

In Ganghwa Island's neighboring big cities, such as Seoul and Incheon, development projects and the discharge of industrial effluent are major issues. In a salt marsh of southern Ganghwa, the zonal distribution of halophytes is related to environmental factors such as salinity and exposure time, and the halophyte community is related to the organic matter content (H. G. Lee et al. 2006, 2016). Despite the size and importance of the Ganghwa Southern tidal flat in the Yellow Sea, few studies have evaluated the relationship between the halophyte community structure and spatial distribution of environmental factors in the tidal flat.

Thus, the objective of this study was to determine whether environmental factors influence the distribution of halophytes in salt marshes of the eastern Yellow Sea. Our results reveal the close relationship between vegetation in salt marshes and various environmental factors, especially soil texture.

\section{Materials and methods}

Study area

The study was conducted in the eastern $\left(37^{\circ} 35^{\prime} 1.13^{\prime \prime} \mathrm{N}\right.$, $126^{\circ} 31^{\prime} 8.17^{\prime \prime}$ E; site 1$)$ and western $\left(37^{\circ} 35^{\prime} 5.44^{\prime \prime} \mathrm{N}, 126^{\circ}\right.$ $30^{\prime} 33.59^{\prime \prime} \mathrm{E}$; site 2) salt marshes of Donggeom Island, southern Ganghwa, South Korea (Fig. 1). The research site

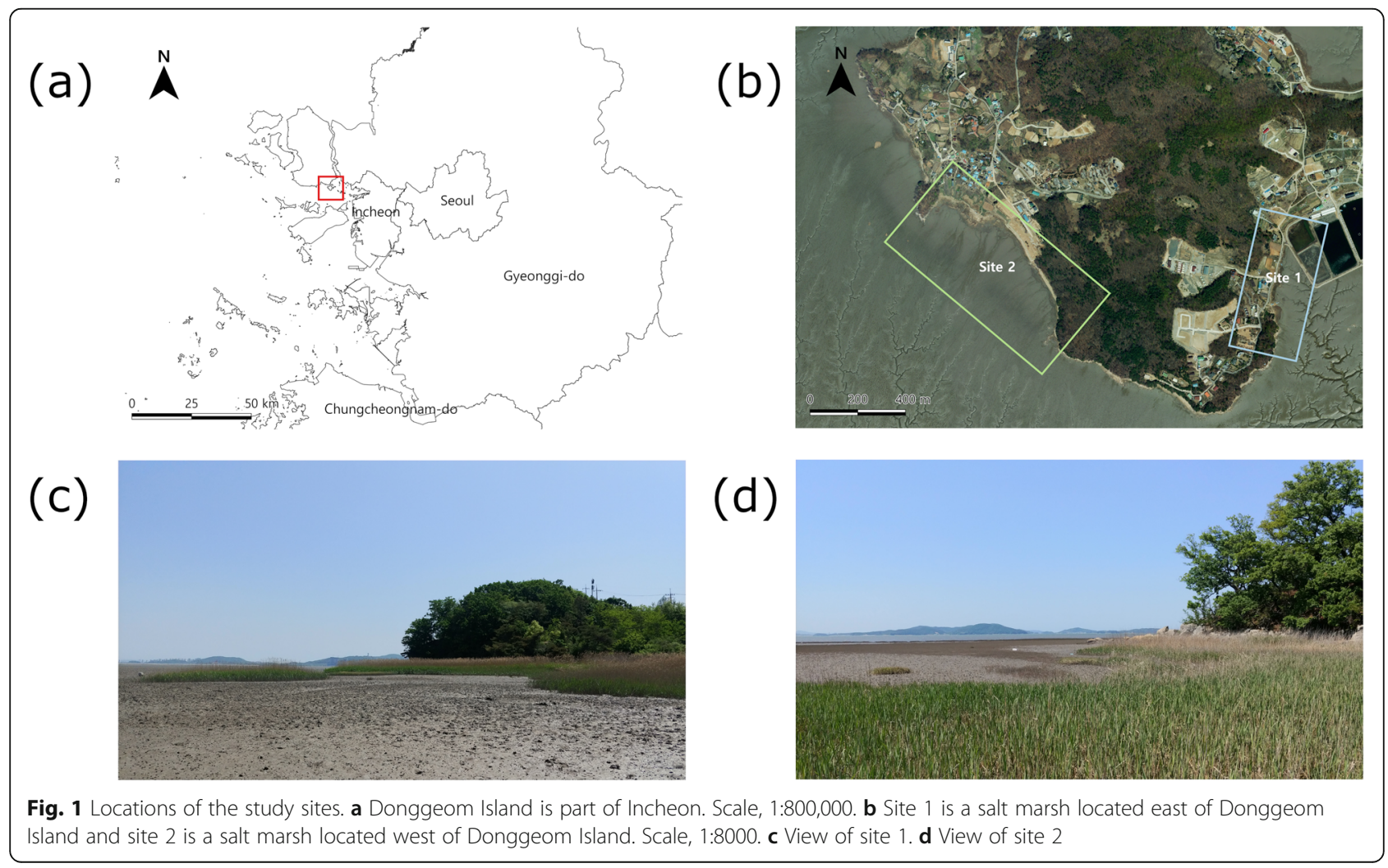


had an annual average temperature of $11.5^{\circ} \mathrm{C}$ over the last 10 years and an average annual rainfall of $1169.9 \mathrm{~mm}$ (Korea Meteorological Administration 2020). The average tidal range, measured from 2016 to 2018 at the tide observation point of Yeongjong Bridge near the research site, was $6.4 \mathrm{~m}$ (Korea Hydrographic and Oceanographic Agency 2017, 2018, 2019).

\section{Field surveys and vegetation mapping}

Vegetation was evaluated by field surveys conducted from July 2020 to October 2020. Scientific names were determined in accordance with the Korea Biodiversity Information System (http://www.nature.go.kr/), except for Spartina anglica, which was identified based on the biodiversity of the Korean Peninsula (https://species. nibr.go.kr/) of the National Institute of Biological Resources (NIBR). For a list of halophytes, the protocol of the National Marine Ecosystem Monitoring Program was followed (Ministry of Oceans and Fisheries/Korea Marine Environment Management Corporation 2019). Based on the area covered by each community (obtained using the network-RTK(Real Time Kinematic) connected to a mobile antenna), 2-25 random points were set in QGIS (Quantum GIS). Temporary quadrats, each measuring $1 \times 1 \mathrm{~m}^{2}$, were installed at these random points. Coordinates, altitude, species and their coverage, bare ground coverage, and individual heights of each species repeated 5 times were recorded for each quadrat (Fig. 2a). Coverage was recorded in increments of $0.05 \%$ for less than $1 \%$ of coverage, $1 \%$ for $1 \%$ to $50 \%$, and $5 \%$ for $50 \%$ or greater. During the low tide period, three soil samples around each quadrat were removed to a depth of $15 \mathrm{~cm}$, placed in a zipper bag, transported to the laboratory, and refrigerated at $4{ }^{\circ} \mathrm{C}$.
The GPS received from network-RTK (PX1122R; NavSpark 2020) was connected to a tablet (SM-T830; Samsung 2018) at the site. Using QField for GIS version 1.5.8 (OPENGIS.ch 2020), polygons representing the boundaries of each community were created at the site and an existing vegetation map was drawn (Fig. 2b). The S. japonica community at Site 2 was spread over a long distance, making it impossible to create polygons by walking the boundaries of the community with an RTK receiver. Thus, a drone (Mavic Pro; DJI Co. 2017) was used to draw a polygon of the S. japonica community. After obtaining images of the area of $S$. japonica with a drone, photos were merged and converted into a single TIFF file using DroneDeploy (https://www.dronedeploy. $\mathrm{com} /$ ). A polygon of the $S$. japonica community was created manually based on the TIFF file (Fig. 2c). The existing vegetation map was completed by correcting errors in the laboratory.

\section{Soil analysis}

The soil samples transported to the laboratory were filtered through a $2-\mathrm{mm}$ sieve to remove gravel and any plant material. Soil texture was determined using a hydrometer and a texture triangle of the USDA (Carter and Gregorich 2007). Soil moisture (SM) was determined after drying samples at $105^{\circ} \mathrm{C}$ in an oven for 24h (Carter and Gregorich 2007). Soil organic matter (SOM) was analyzed by burning the dried samples at $550{ }^{\circ} \mathrm{C}$ for $4 \mathrm{~h}$ (Boyle 2004). Soil solutions were prepared by mixing $5 \mathrm{~g}$ of soil sample with 60 $\mathrm{ml}$ of distilled water in a $50-\mathrm{ml}$ conical tube; $\mathrm{pH}$ and salinity were measured using a PC-2000 (THERMO EUTECH, Singapore). (a)

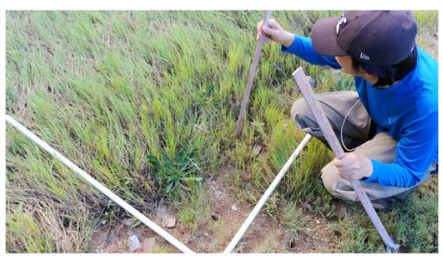

(b)

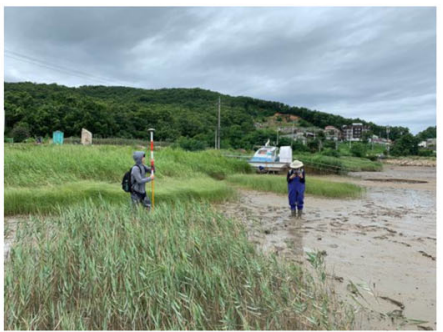

(c)

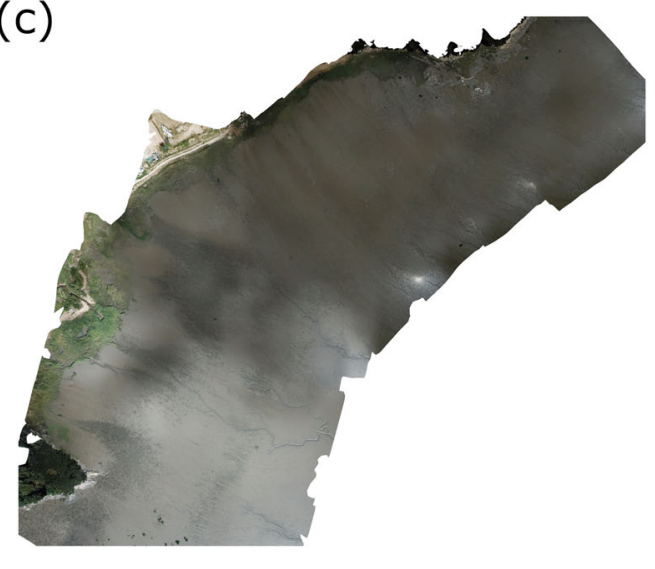

Fig. 2 Parts of the field survey. a Briefly, $1 \times 1 \mathrm{~m}^{2}$ quadrats were used to survey coverages and heights of species. $\mathbf{b}$ Vegetation maps were constructed with network-RTK GPS. c A map showing the Suaeda japonica distribution by merging images obtained by a drone. North is on the left 


\section{Statistical analysis}

Correlations between environmental factors were evaluated by Pearson's correlation coefficients. Environmental factors included altitude, SM, SOM content, soil salinity, $\mathrm{pH}$, and soil texture. Altitude was determined by inputting the coordinates and ellipsoid height obtained by network-RTK into the national geoid model KNGeoid18. Permutational multivariate analysis of variance (PERMANOVA) was performed using the "vegan" package in $\mathrm{R}$ (Oksanen et al. 2020) to determine whether the group classification obtained using NbClust was related to measured environmental factors. Dunn's test was used to identify environmental factors with significant differences among groups (Ogle et al. 2021). For groups, the similarity in emergent species between quadrats were visualized by non-metric multidimensional scaling (NMDS) based on the Bray-Curtis dissimilarity matrix.

To evaluate the relationships between vegetation and environmental factors, a canonical correspondence analysis (CCA) was performed using the "vegan" package. In addition, spatial interpolation was used to visually evaluate variation in each environmental factor. In the case of soil-related factors, ordinary kriging was performed owing to its high predictive power for spatial distributions (Zare-Mehrjardi et al. 2010). For this, Moran's I was calculated using the "spdep" package (Bivand et al. 2009) to detect spatial autocorrelation. In the case of spatial autocorrelation, a semi-variogram was drawn, modeled, and used for kriging. Semi-variogram preparation, kriging, and inverse distance weighting were performed using the "gstat" package (Pebesma 2004). All analyses were conducted using R 4.0.3.

\section{Results \\ Identification of three vegetation groups by cluster analysis}

We found 61 species in the study area (Appendix 1), including 20 of the 135 species defined as halophytes in the Protocol of National Marine Ecosystem Monitoring Program. A cluster analysis based on the presence/absence and coverage data for species identified in 128 quadrats identified three groups: group A, including only $P$. communis; group $\mathrm{B}$, including only $S$. japonica; and group C, including other halophytes (Fig. 3). Group C included Triglochin maritima L., Zoysia sinica Hance, Carex scabrifolia Steud., Phacelurus latifolius (Steud.) Ohwi, Artemisia fukudo Makino, Carex pumila Thunb., S. anglica, Suaeda maritima (L.) Dumort, Suaeda glauca (Bunge) Bunge, and Limonium tetragonum (Thunb.) Bullock communities. In particular, the $S$. japonica community was sparsely distributed in the tidal flat (Appendix 2, Fig. 4).

As shown in Fig. 4, the $P$. communis community was well-established. In the sandy beach to the east of site 2,

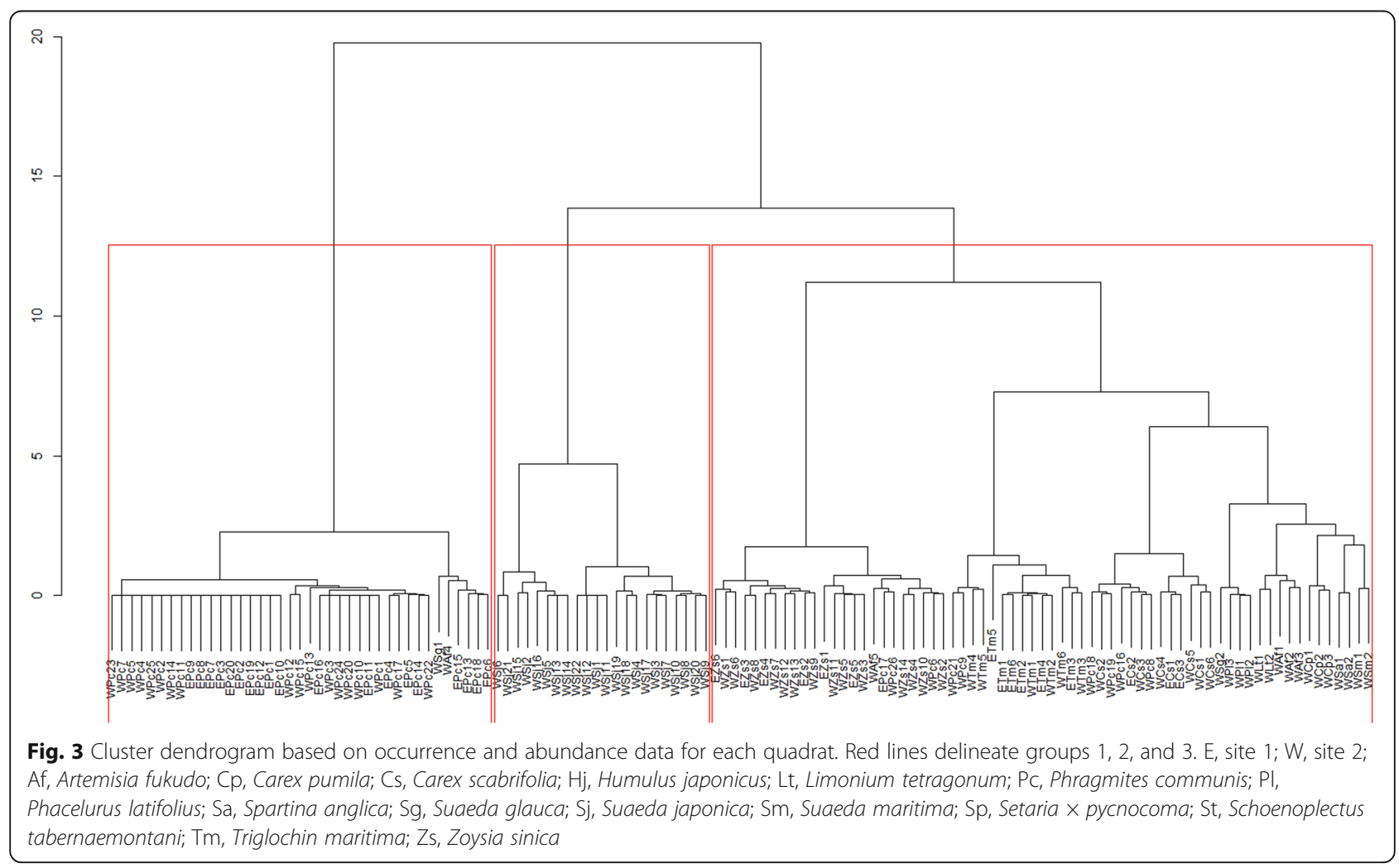


(a)

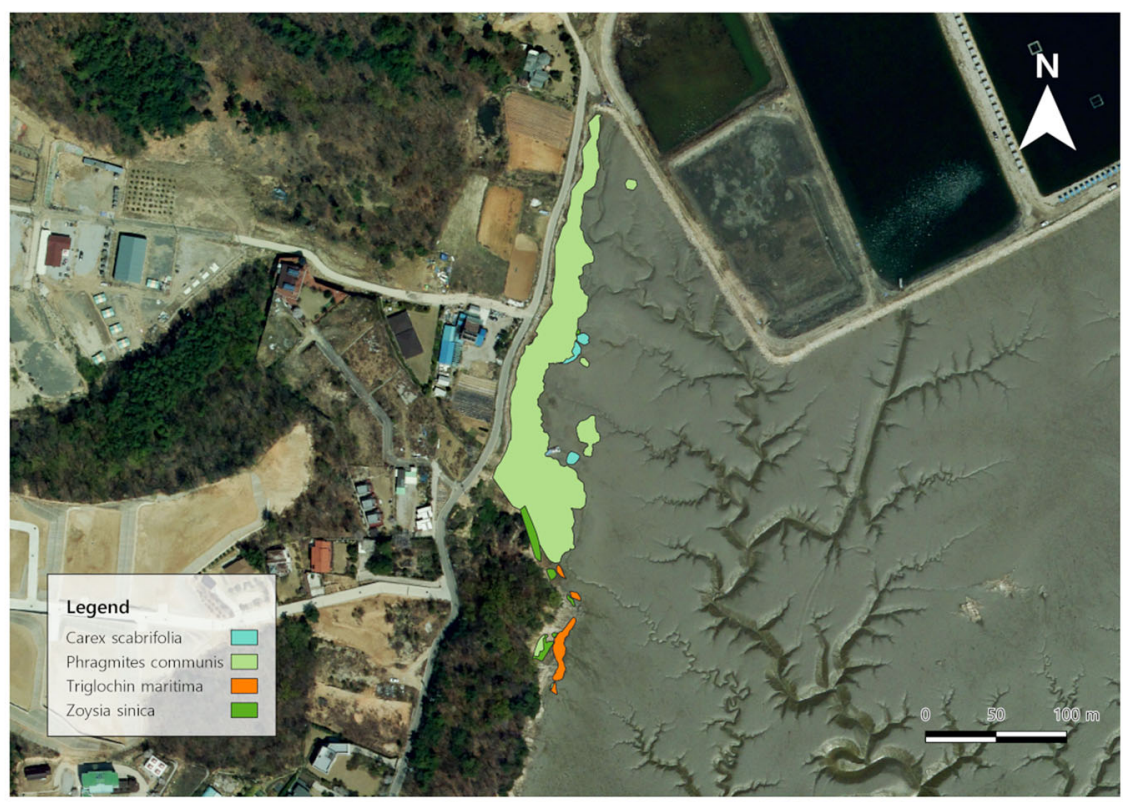

(b)

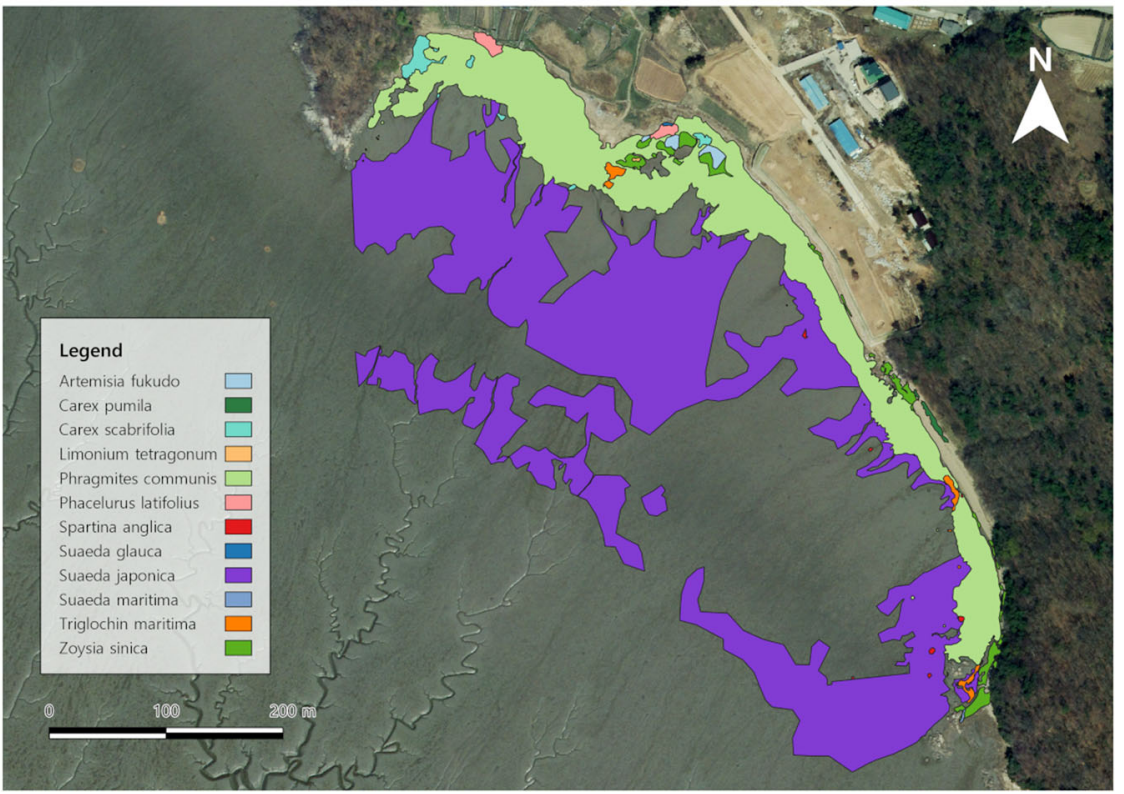

Fig. 4 Vegetation map of the study sites surveyed in 2020. a Site 1. b Site 2

sand dune plants such as C. pumila formed a community. The salt marsh was very large and included a mixed community of various species. There were two composition types, one in which only $P$. communis was detected, and another in which T. maritima, C. scabrifolia, and Schoenoplectus tabernaemontani (C.C.Gmel.) Palla were found in the lower layer, despite a high $P$. communis cover of $\geq 80 \%$ in the upper layer. The A. fukudo community occurred together with $P$. communis and $Z$. sinica. The C. scabrifolia community appeared frequently with $P$. communis in the upper layer (Fig. 5). The L. tetragonum community coexisted with Z. sinica and A. fukudo. The S. glauca community appeared with $P$. latifolius and $P$. communis. The $Z$. sinica community appeared with $P$. communis, $L$. tetragonum, A. fukudo, and S. maritima.

NMDS confirmed the species distribution of group B (Fig. 6). Group $\mathrm{C}$ was more broadly distributed than group A. C. pumila and S. japonica did not appear frequently with other plants. A. fukudo, $Z$. sinica, and $L$. tetragonum co-existed with S. maritima, and C. scabrifolia was found together with $P$. communis and S. tabernaemontani. Glycophytes, Humulus japonicus Siebold \& Zucc., Setaria $\times$ pycnocoma (Steud.) Henrard ex Nakai, and $P$. latifolius co-existed. 


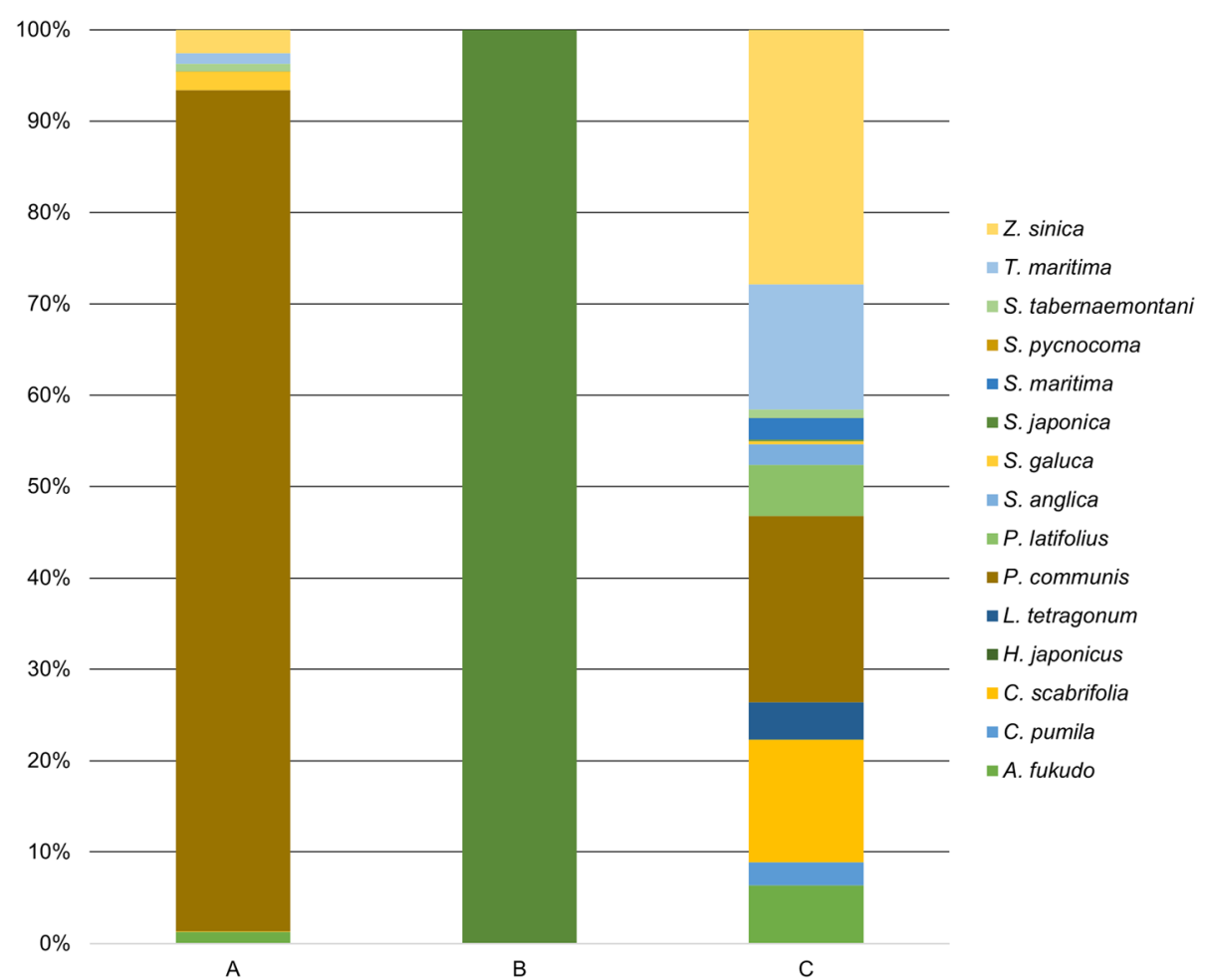

Fig. 5 Average coverage of species in the three groups. Average coverage of each species in the quadrats for each group is presented as a proportion of the total area

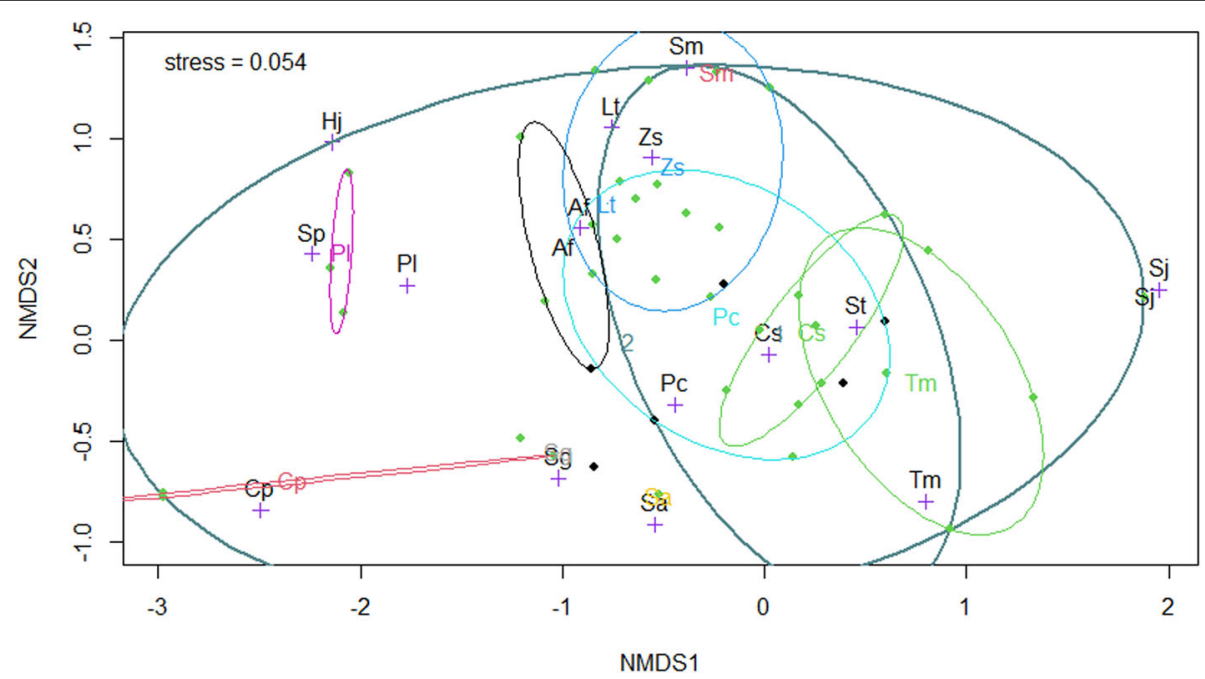

Fig. 6 NDMS ordination based on Bray-Curtis dissimilarity distances. Cross symbols show ordinations of species. Points show ordinations of quadrats. Black points are quadrats containing group A, and green points are quadrats containing group C. Ellipses show the species abundance and range of the study sites, and the dominant vegetation groups. Abbreviations are the same as those defined in Fig. 4 
Environmental conditions in the eastern Yellow Sea In addition to 128 quadrats with halophyte vegetation, 12 control quadrats were installed to analyze the SM, SOM content, $\mathrm{pH}$, salinity, and soil texture (Table 1). Based on a soil texture analysis, in group B (containing only S. japonica), the silt content was the highest among the three soil elements. This group was mainly found in areas with silt $(Z)$ and sandy silt (sZ) (Fig. 7). Group A was found in a relatively wide range of sand and silt conditions. Species in Group $\mathrm{C}$ were distributed in areas with a high proportion of silt, such as T. maritima and C. scabrifolia, and in areas with a high proportion of sand, such as Z. sinica and C. pumila. Thus, this group showed a wide range of soil textures. In the control areas lacking halophytes, sand (S) was predominant in quadrats installed near the C. pumila community, while sandy silt (sZ) or silt (Z) was predominant in quadrats installed near $S$. japonica and other halophytes.

We detected significant correlations between altitude $(p<0.05)$ and all environmental variables examined (Fig. 8). Altitude was positively correlated $(r=0.53)$ with the sand content and negatively correlated $(r=-$ 0.56 ) with silt. SM was positively correlated with SOM and silt ( $r=0.82$ and $r=0.81$, respectively). SOM showed a negative correlation $(r=-0.76)$ with the sand content and positive correlations with clay and silt contents $(r=0.75$ and $r=0.72$, respectively). There were no significant correlations between $\mathrm{pH}$ and other factors, except altitude. The sand content was negatively correlated with clay and silt contents $(r=-0.86$ and $r$ $=-0.98$, respectively).

PERMANOVA revealed significant differences among the three groups $(p<0.05)$ with respect to altitude, SM, SOM, salinity, sand, silt, and clay contents (but not $\mathrm{pH}$ ). Dunn's test for environmental factors other than $\mathrm{pH}$ further revealed that parameter values typically differed between group B and groups A and
C. The altitude of group B, dominated by S. japonica, was lower than that of other groups. Furthermore, SOM content differed among groups (Table 1).

In a CCA of relationships between each group and environmental factors, CCA1 explained $8.8 \%$ of the total variance (eigenvalue 0.6850) and CCA2 explained $6.2 \%$ of the total variance (eigenvalue 0.4845) (Fig. 9). In the positive direction along CCA1, the silt and clay contents, SM, SOM content, and salinity tended to increase, while the altitude and sand content tended to decrease (silt, 0.79; clay, 0.40; soil moisture, 0.65 ; soil organic matter content, 0.31 ; salinity, 0.52 ; altitude, -0.47 ; sand, -0.70 ). Species best explained by CCA1 were glycophytes, as well as Setaria $\times$ pycnocoma $(\mathrm{Sp})$ and $S$. japonica $(\mathrm{Sj})$, the pioneer halophytes. In the positive direction along CCA2, SM and clay contents tended to increase and $\mathrm{pH}$ and salinity tended to decrease (SM, 0.40; clay, 0.31; $\mathrm{pH},-0.31$; salinity, -0.36). Species best explained by CCA2 were $S$. glauca (Sg), Setaria $\times$ pycnocoma (Sp), S. maritima $(\mathrm{Sm})$, and $H$. japonicus $(\mathrm{Hj})$. Group A was found at a wide range of altitudes and in areas with lower salinity than the average. $P$. communis tended to overlap with other taxa, while $S$. japonica was frequently found alone in areas with high salinity. The silt content, SOM content, SM, and clay content showed similar trends in the CCA.

\section{Spatial distribution of environmental conditions}

To visualize variation in environmental factors at the study sites, kriging was used for spatial interpolation. Moran's $I$ revealed positive spatial autocorrelation for $\mathrm{SM}, \mathrm{pH}$, sand, clay, and silt at site 1 . Site 2 had positive spatial autocorrelation for altitude, SM, SOM, sand, clay, silt, and salinity. Based on a semivariogram for environmental factors, kriging showed spatial autocorrelation (Fig. 10). We observed that, in general, SM for group A was lower than that in other

Table 1 Summary of environmental conditions for the three clusters (A, B, and C) and the control groups with means. Standard deviations are presented in parentheses. Superscript letters indicate significant differences between clusters based on Dunn's test, $p<0.05$

\begin{tabular}{lllll}
\hline & A & B & C & \multicolumn{1}{c}{ Control } \\
\hline Altitude (m) & $3.71(1.26)^{a}$ & $2.82(0.23)^{\mathrm{b}}$ & $3.89(0.73)^{\mathrm{a}}$ & $3.31(0.69)$ \\
Soil moisture (\%) & $14.70(5.03)^{\mathrm{a}}$ & $17.51(1.70)^{\mathrm{b}}$ & $11.96(5.29)^{\mathrm{c}}$ & $13.54(5.83)$ \\
Soil organic matter (\%) & $1.28(0.62)^{\mathrm{a}}$ & $1.70(0.25)^{\mathrm{b}}$ & $1.24(0.67)^{\mathrm{a}}$ & $1.33(0.57)$ \\
$\mathbf{p H}$ & $6.89(0.54)$ & $7.23(0.17)$ & $7.04(0.59)$ & $7.73(0.49)$ \\
Salinity (ppm) & $634.57(620.74)^{\mathrm{a}}$ & $1508.54(367.09)^{\mathrm{b}}$ & $564.33(548.07)^{\mathrm{a}}$ & $1036.58(537.65)$ \\
Sand (\%) & $45.97(35.33)^{\mathrm{a}}$ & $8.71(8.11)^{\mathrm{b}}$ & $60.39(26.3)^{\mathrm{a}}$ & $35.64(36.16)$ \\
Clay (\%) & $15.29(12.33)^{\mathrm{a}}$ & $17.73(6.02)^{\mathrm{b}}$ & $10.59(8.40)^{\mathrm{a}}$ & $12.91(9.17)$ \\
Silt (\%) & $38.74(23.74)^{\mathrm{a}}$ & $73.55(4.85)^{\mathrm{b}}$ & $29.23(19.00)^{\mathrm{a}}$ & $51.45(30.10)$ \\
\hline
\end{tabular}



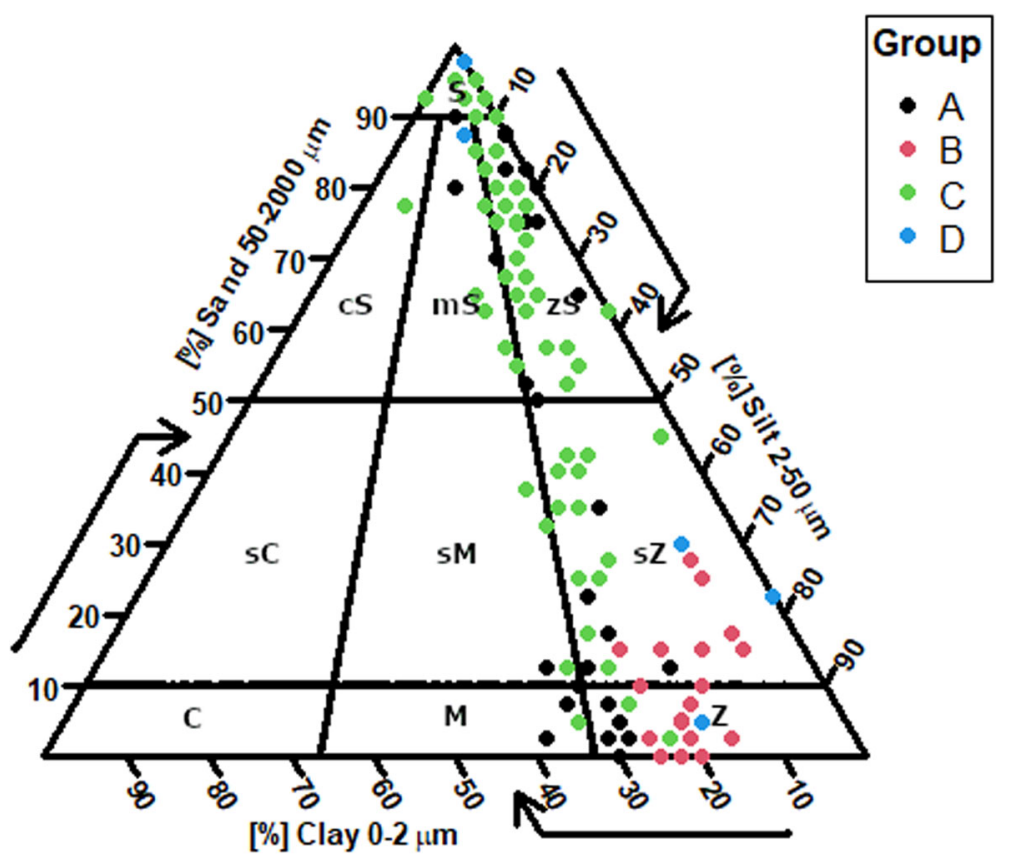

Fig. 7 Soil texture graph. Groups A-C correspond to the groups obtained by cluster analysis. Group D: control quadrats. Soil classification is based on Folk (1980)

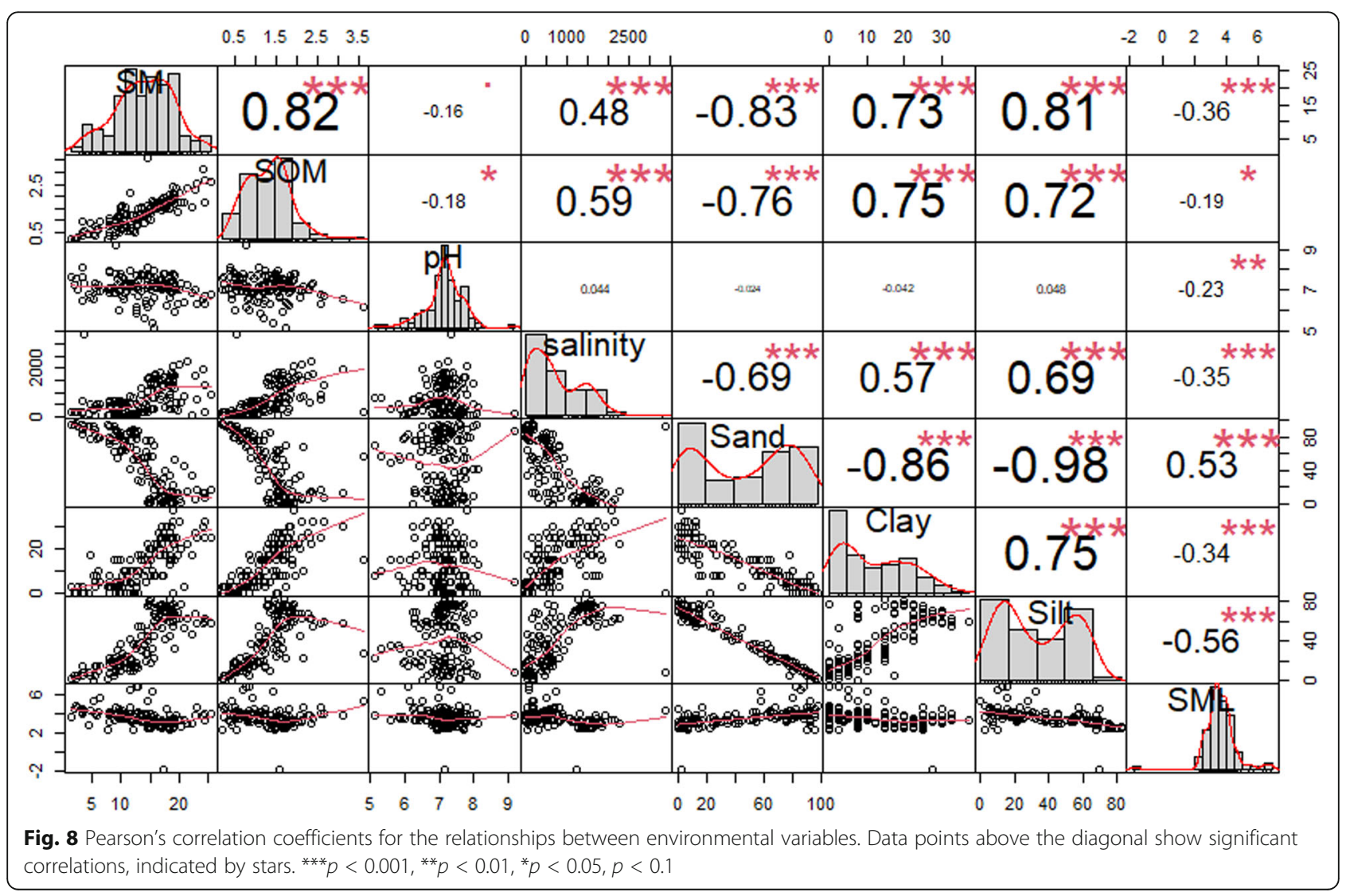




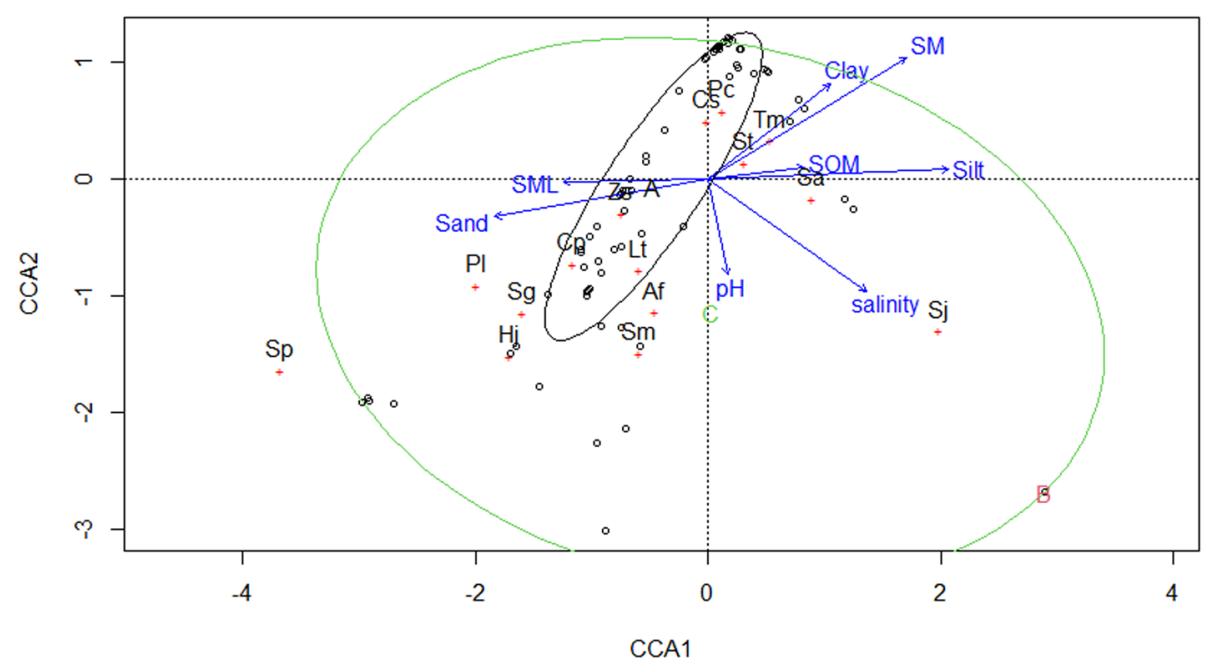

Fig. 9 Summary of the CCA results. Cross marks denote ordination of species. Ellipses denote groups determined by the cluster analysis. Abbreviations are the same as those defined in Fig. 4. Unfilled dots denote the quadrats examined. SML, altitude; SOM, soil organic matter; SM, soil moisture. Ordination of CCA considers species abundance and environmental factors

areas (Fig. 10a, f). Additionally, the soil of group A had a lower silt content than those of other areas in the salt marsh (Fig. 10e, k). For some parameters, predictive power deteriorated, even if the distance from the quadrats was greater.

\section{Discussion}

Our results confirmed that the structure of the salt marsh community is closely related to the values and spatial distribution of environmental factors. The plant community in salt marshes in the southern region of Ganghwa could be divided into group A, dominated by $P$. communis; group B, dominated by $S$. japonica; and group $\mathrm{C}$, dominated by halophytes other than S. japonica and P. communis. There were significant differences in SM, SOM, salinity, soil texture, and altitude among groups. In particular, environmental conditions associated with group B were significantly different from those of other groups. Pioneer species such as S. japonica can survive at lower altitudes due to their strong salt tolerance, and can emerge in soils with high silt ratios (van Regteren et al. 2020; Kim 2018a).

In a CCA of the major environmental factors influencing the distribution of halophytes, the proportion of sand increased as the altitude increased, while SM, silt, clay, and SOM contents, and salinity tended to decrease. Group A, dominated by P. communis, was found in areas with lower than average salinity, as observed previously in the Siheung salt marsh (Bang et al. 2018). By contrast, the salinity of Phragmites habitats is higher than that of Carex habitats in China (Cui et al. 2021).
In an analysis of 128 quadrats with halophyte vegetation and 12 control quadrats with no vegetation, mainly sand (S), silty sand (zS), sandy silt (sZ), and silt $(Z)$ sedimentary facies were detected. These were similar to sedimentary facies in the tidal flat along the west coast determined by the National Marine Ecosystem Monitoring Program from 2015 to 2019 (Ministry of Oceans and Fisheries 2019). Contents of sand and silt for group $\mathrm{A}$, where the $P$. communis community dominated, varied substantially, with average values of $45.97 \%$ and $15.29 \%$, respectively. Previously reported contents of sand and clay in coastal salt marshes with $P$. communis were $82.81 \%$ and $4.85 \%$, respectively, in southern Korea (Cho, Lee, and Kim 2017), and $2.0 \%$ and $44.8 \%$, respectively, in Suncheon Bay (Jang et al. 2013), revealing large differences in soil texture among habitats. There were differences in SM, SOM, salinity, soil texture, and altitude between group B and other groups. Pioneer species such as $S$. japonica have strong salt tolerance and can survive at relatively low altitudes. They are likely to emerge in soils with a relatively high silt content, as the species shows better seeding settlement in soils with small grain sizes, such as silt or clay, than in sand (van Regteren et al. 2020; Kim 2018a).

Altitude correlated significantly with all measured environmental factors. The physical environment varies among altitudes, including variation in the time submerged in seawater and differences in size of sediment particles swept away by waves. Furthermore, different halophyte communities are associated with chemical differences in soil (Bart and Hartman 2000; Santelmann et al. 2019; van Regteren et al. 2020). 


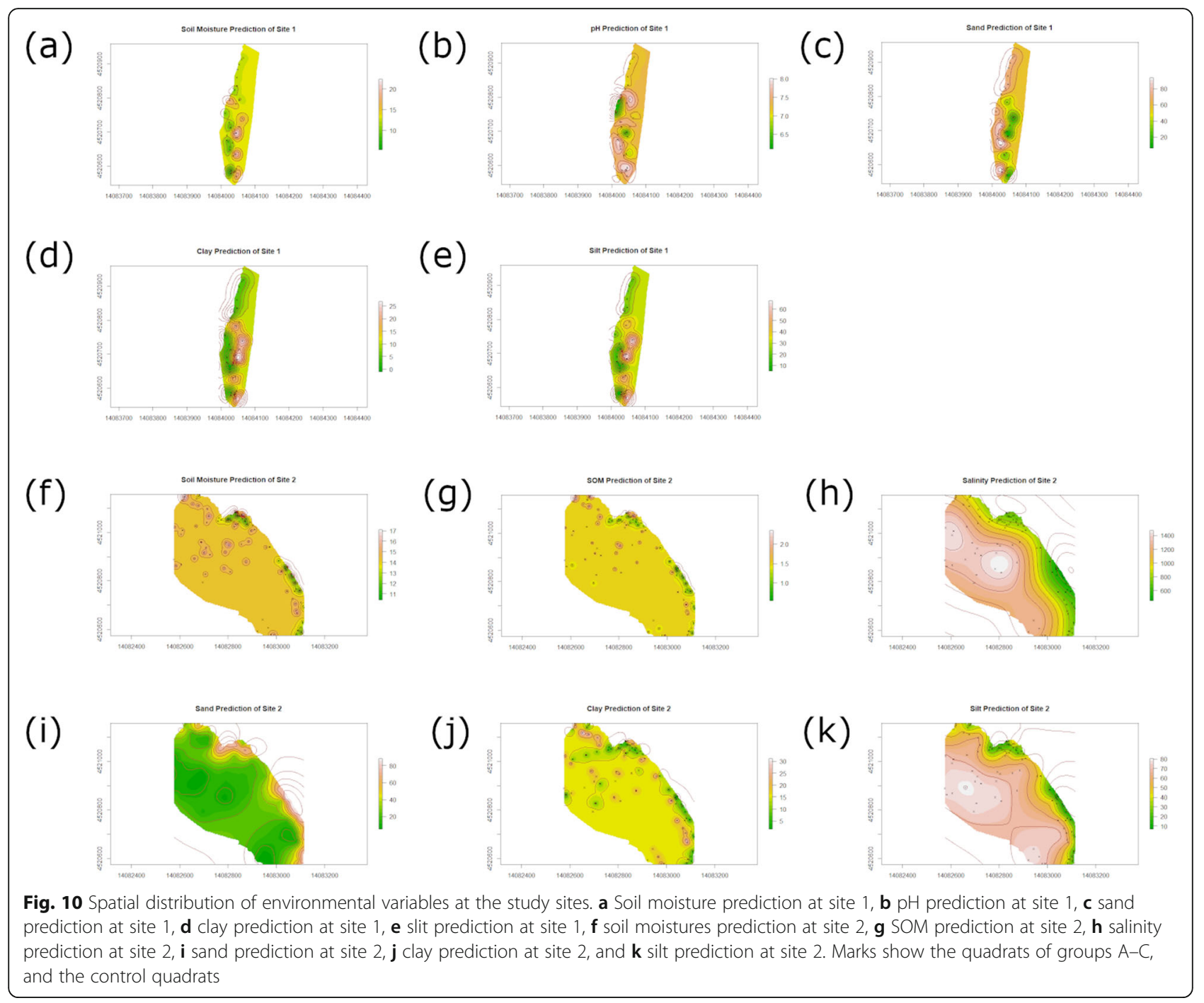

Regarding the halophyte community in southern Ganghwa, a higher altitude was associated with a higher sand content and lower SM, silt and clay contents, SOM content, and salinity. In the late 1990s, southern Ganghwa was primarily a silt-rich muddy tidal flat. However, due to large-scale development near Ganghwa Island in the 1990s, currents changed, resulting in continuous sedimentation in southern Ganghwa. The soil texture changed gradually to a sandy mud tidal flat because the sediment is largely sand (Woo 2013). These changes are consistent with the CCA results in the present study, showing that the higher the altitude, the higher the sand content. In this study, the salinity of group A (dominated by P. communis) was lower than the average salinity, similar to results for the Siheung salt marsh (Bang et al. 2018). Freshwater influx explains the appearance of $P$. communis in salt marshes, and the rapid range expansion (Bart and Hartman 2000). Site 1 also maintained a relatively low salinity due to the presence of drainage holes for freshwater inflow. This appears to have become a source area allowing expansion toward oceans with high salinity (Hong 2015).

\section{Conclusion}

We characterized the halophyte composition in the tidal flats of southern Ganghwa and evaluated the spatial relationship between the distribution of halophytes and environmental factors. A cluster analysis revealed that the halophyte communities in the study area could be assigned to three groups: $P$. communis, S. japonica, and other halophyte communities. The S. japonica community was distributed in areas with a relatively high silt content. The $P$. communis community appeared in a wider range of soil textures than those reported in the literature. These results provide essential information about changes in spatial distribution in salt marshes, which may facilitate conservation or restoration. 


\section{Appendix 1}

Table $\mathbf{2}$ List of plant species observed at the study sites. Taxa marked with an asterisk are halophytes classified by KOEM (2019)

\begin{tabular}{|c|c|}
\hline Family & Species \\
\hline \multirow[t]{3}{*}{ Amaranthaceae } & Achyranthes japonica (Miq.) Nakai \\
\hline & Amaranthus retroflexus L. \\
\hline & Portulaca oleracea L. \\
\hline Cannabaceae & Humulus japonicus Siebold \& Zucc. \\
\hline \multirow[t]{2}{*}{ Caryophyllaceae } & Cucubalus baccifer var. japonicus Miq. \\
\hline & Spergularia marina (L.) Besser* \\
\hline \multirow[t]{6}{*}{ Chenopodiaceae } & Chenopodium album var. centrorubrum Makino \\
\hline & Chenopodium ficifolium Smith \\
\hline & Salsola komarovii \|ljin* \\
\hline & Suaeda glauca (Bunge) Bunge* \\
\hline & Suaeda japonica Makino \\
\hline & Suaeda maritima (L.) Dumort* \\
\hline Commelinaceae & Commelina communis L. \\
\hline \multirow[t]{11}{*}{ Compositae } & Ambrosia artemisiifolia $\mathrm{L}$. \\
\hline & Artemisia capillaris Thunb.* \\
\hline & Artemisia fukudo Makino* \\
\hline & Artemisia princeps Pamp. \\
\hline & Bidens bipinnata $\mathrm{L}$. \\
\hline & Conyza canadensis (L.) Cronquist \\
\hline & Conyza sumatrensis E.Walker \\
\hline & Eclipta prostrata (L.) L. \\
\hline & Erechtites hieracifolia Raf. \\
\hline & Sigesbeckia pubescens (Makino) Makino \\
\hline & Sonchus brachyotus DC* \\
\hline Convolvulaceae & Calystegia soldanella (L.) Roem. \& Schult* \\
\hline Cruciferae & Capsella sp. \\
\hline \multirow[t]{5}{*}{ Cyperaceae } & Bolboschoenus planiculmis (F.Schmidt) T.V.Egorova* \\
\hline & Carex scabrifolia Steud.* \\
\hline & Carex pumila Thunb.* \\
\hline & Cyperus amuricus Maxim. \\
\hline & Schoenoplectus tabernaemontani (C.C.Gmel.) Palla \\
\hline \multirow[t]{2}{*}{ Fagaceae } & Castanea crenata Siebold \& Zucc. \\
\hline & Quercus acutissima Carruth. \\
\hline \multirow[t]{10}{*}{ Gramineae } & Digitaria ciliaris (Retz.) Koel. \\
\hline & Echinochloa crus-galli (L.) P.Beauv. \\
\hline & $\begin{array}{l}\text { Miscanthus sinensis var. purpurascens (Andersson) } \\
\text { Rendle }\end{array}$ \\
\hline & Panicum bisulcatum Thunb. \\
\hline & Phacelurus latifolius (Steud.) Ohwi* \\
\hline & Phragmites communis Trin.* \\
\hline & Setaria faberii Herrm. \\
\hline & Setaria viridis (L.) P.Beauv. \\
\hline & Setaria x pycnocoma (Steud.) Henrard ex Nakai \\
\hline & Spartina anglica C.E.Hubb.* \\
\hline
\end{tabular}

Table 2 List of plant species observed at the study sites. Taxa marked with an asterisk are halophytes classified by KOEM (2019) (Continued)

\begin{tabular}{|c|c|}
\hline Family & Species \\
\hline & Themeda triandra var. japonica (Willd.) Makino \\
\hline & Zoysia sinica Hance* \\
\hline Juncaceae & Juncus haenkei E.Mey.* \\
\hline Juncaginaceae & Triglochin maritima L.* \\
\hline Labiatae & Leonurus japonicus Houtt. \\
\hline \multirow[t]{3}{*}{ Leguminosae } & Amorpha fruticosa $\mathrm{L}$. \\
\hline & Pueraria lobata (Willd.) Ohwi \\
\hline & $\begin{array}{l}\text { Vigna angularis var. nipponensis (Ohwi) Ohwi } \\
\text { \& H.Ohashi }\end{array}$ \\
\hline Malvaceae & Abutilon theophrasti Medicus \\
\hline Menispermaceae & Cocculus trilobus (Thunb.) DC. \\
\hline Oxalidaceae & Oxalis stricta L. \\
\hline Pinaceae & Pinus densiflora Siebold \& Zucc. \\
\hline Plumbaginaceae & Limonium tetragonum (Thunb.) Bullock* \\
\hline \multirow[t]{3}{*}{ Polygonaceae } & Persicaria longiseta (Bruijn) Kitag. \\
\hline & Polygonum bellardii All.* \\
\hline & Rumex crispus L. \\
\hline Portulacaceae & Portulaca oleracea $\mathrm{L}$. \\
\hline Solanaceae & Datura meteloides DC. ex Dunal \\
\hline Vitaceae & $\begin{array}{l}\text { Parthenocissus tricuspidata (Siebold \& Zucc.) } \\
\text { Planch. }\end{array}$ \\
\hline Number of species & 61 \\
\hline
\end{tabular}

\section{Appendix 2}

Table 3 Area of vegetation in each salt marsh $\left(\mathrm{m}^{2}\right)$. Values in parentheses indicate the number of quadrats surveyed

\begin{tabular}{|c|c|c|c|}
\hline Species & A & B & C \\
\hline Artemisia fukudo Makino & & & $222.6(5)$ \\
\hline Carex pumila Thunb. & & & $100.3(3)$ \\
\hline Carex scabrifolia Steud. & & & $573.1(9)$ \\
\hline $\begin{array}{l}\text { Limonium tetragonum } \\
\text { (Thunb.) Bullock }\end{array}$ & & & $11.2(2)$ \\
\hline Phragmites communis Trin. & $\begin{array}{l}22,683.3 \\
(46)\end{array}$ & & \\
\hline $\begin{array}{l}\text { Phacelurus latifolius (Steud.) } \\
\text { Ohwi }\end{array}$ & & & $280.4(3)$ \\
\hline Spartina anglica C.E.Hubb. & & & $48.1(2)$ \\
\hline Suaeda glauca (Bunge) Bunge & & & $12.3(2)$ \\
\hline Suaeda japonica Makino & & $\begin{array}{l}45,236.3 \\
(22)\end{array}$ & \\
\hline Suaeda maritima (L.) Dumort & & & $15.2(2)$ \\
\hline Triglochin maritima L. & & & $528.8(12)$ \\
\hline Zoysia sinica Hance & & & $\begin{array}{l}1344.7 \\
(20)\end{array}$ \\
\hline $\begin{array}{l}\text { Total vegetated salt } \\
\text { marsh area }\end{array}$ & $22,683.3$ & $45,236.3$ & 3136.7 \\
\hline
\end{tabular}




\section{Abbreviations}

CCA: Canonical correspondence analysis; NMDS: Non-metric multidimensional scaling; PERMANOVA: Permutational multivariate analysis of variance; QGIS: Quantum geographic information system; RTK: Real time kinematic

\section{Acknowledgements}

We appreciate all our Laboratory of Plant Ecology members, especially Minwoo Oh, Minki Hong, Yoon Jeong Heo, and Keon Seok Kim, for helping field surveys.

\section{Authors' contributions}

JC carried out the field study, performed the analysis, and wrote the manuscript. JHK participated in the field study and wrote and reviewed the manuscript. EJL conceived the study and reviewed the manuscript. JC and JHK made equal contributions to this study. All authors read and approved the final manuscript.

\section{Funding}

This work was supported by the Korea Environment Industry \& Technology Institute (KEITI) through The Decision Support System Development Project for Environmental Impact Assessment, funded by the Korea Ministry of Environment (MOE) (2021003360002), and the National Research Foundation of Korea, funded by the government (Ministry of Science and ICT) (No. 2020R1F1A107295811)

\section{Availability of data and materials}

The datasets generated and/or analyzed during the current study are available from the corresponding author upon reasonable request.

\section{Declarations}

\section{Ethics approval and consent to participate}

Not applicable.

\section{Consent for publication}

Not applicable.

\section{Competing interests}

The authors declare that they have no competing interests.

\section{Author details}

'DMZ Botanic Garden, Korea National Arboretum, Yanggu 24564, Republic of Korea. ${ }^{2}$ Research Institute for Agriculture and Life Sciences, Seoul National University, Seoul 08826, Republic of Korea. ${ }^{3}$ DMZ Ecology Research Institute, Paju 10881, Republic of Korea. ${ }^{4}$ School of Biological Sciences, Seoul National University, Seoul 08826, Republic of Korea.

Received: 24 August 2021 Accepted: 25 October 2021

Published online: 04 December 2021

\section{References}

Bang JH, Bae MJ, Lee EJ. Plant distribution along an elevational gradient in a macrotidal salt marsh on the west coast of Korea. Aquatic Botany. 2018; 147(August 2017):52-60. https://doi.org/10.1016/j.aquabot.2018.03.005.

Bart D, Hartman JM. Environmental determinants of Phragmites australis expansion in a New Jersey salt marsh: an experimental approach. OIKOS. 2000;89(1):59-69. https://doi.org/10.1034/j.1600-0706.2000.890107.x.

Bertness MD, Ellison AM. Determinants of pattern in a New England salt marsh plant community. Ecol Monogr. 1987;57(2):129-47. https://doi.org/10.2307/1 942621.

Bivand R, Müller WG, Reder M. Power calculations for global and local Moran's I. Comput Stat Data Anal. 2009;53(8):2859-72. https://doi.org/10.1016/j.csda.2 008.07.021.

Boyle J. A comparison of two methods for estimating the organic matter content of sediments. J Paleolimnol. 2004;31(1):125-7. https://doi.org/10.1023/B:JOPL. 0000013354.67645.df

Brereton AJ. The structure of the species populations in the initial stages of saltmarsh succession. J Ecol. 1971;59(2):321-38. https://doi.org/10.2307/2258314.

Carter MR, Gregorich EG. Soil sampling and methods of analysis. CRC press; 2007. https://doi.org/10.1201/9781420005271.ch57.
Cho JS, Lee JS, Kim JW. Distribution of Phragmites australis communities with different habitat salinity. J Coastal Res. 2017:33(5):1210-6. https://doi.org/1 0.2112/JCOASTRES-D-16-00065.1.

Colmer TD, Flowers TJ. Flooding tolerance in halophytes. New Phytol. 2008; 179(4):964-74. https://doi.org/10.1111/j.1469-8137.2008.02483.x.

Cui Q, He T, Zhang A, Quan X, Feng Y, Chen X, et al. Effects of soil salinity characteristics on three habitats in inland salt marshes. J Plant Res. 2021; 134(5):1037-46. https://doi.org/10.1007/s10265-021-01328-x.

Hong MG. Effects of freshwater inflow, salinity, and water level on the growth of common reed in salt marsh: Seoul National University; 2015.

Ihm BS, Lee JS, Kim JW, Kim JH. Coastal plant and soil relationships along the southwestern coast of South Korea. J Plant Biol. 2007;50(3):331-5. https://doi. org/10.1007/BF03030663.

Jang H, Gong J, Kong B, Han S, Ra D, Cheong C. Distribution pattern of halophytes and its soil environment of the saltmarsh in the Sunheon Bay. J Korean Soc Environ Technol. 2013;14(6):399-410.

Kim D. Characterizing the pathway and rate of salt marsh vegetation dynamics: a multivariate approach. Estuaries and Coasts. 2018;41(5):1370-80. https://doi. org/10.1007/s12237-018-0377-8.

Korea Hydrographic and Oceanographic Agency. Annual Report of Korea Oceanographic Observation Network (2016) 2017;

Korea Hydrographic and Oceanographic Agency. Annual Report of Korea Oceanographic Observation Network (2017) 2018;

Korea Hydrographic and Oceanographic Agency. Annual report of Korea Oceanographic Observation Network (2018) 2019;

Korea Meteorological Administration. Weather Data Opening Portal 2020; Retrieved December 15, 2020, from https://data.kma.go.kr/cmmn/main.do

Lee HG, Park HS, Hong JS, Je JG, Lee JH. Spatio-temporal variation in the benthic environmental conditions and salt marsh vegetation in Donggeomdo, Incheon, Korea. Korean J Fisheries Aquat Sci. 2006;39(spc1):180-8. https://doi. org/10.5657/kfas.2006.39.spc1.180

Lee HG, Yoon KT, Park HS, Hong JS, Lee JH. The influence of environmental variables on distribution of macrobenthic community in salt marsh vegetation in donggeomdo, Ganghwa on the west coast of Korea. Ocean Polar Res. 2016;38(2):115-28. https://doi.org/10.4217/OPR.2016.38.2.115.

Lee Y-K, Park W, Choi JK, Ryu JH, Won JS. Halophyte die-off in response to anthropogenic impacts on tidal flats. Estuarine, Coastal and Shelf Science. 2014;151:347-54. https://doi.org/10.1016/j.ecss.2014.09.009.

Ministry of Oceans and Fisheries. Annual Report of National Marine Ecosystem Monitoring Program (2019) 2019;

Ministry of Oceans and Fisheries. Marine Environment Information Map 2020;

Ministry of Oceans and Fisheries / Korea Marine Environment Management Corporation. Protocol of National Marine Ecosystem Monitoring Program. 3rd ed; 2019.

Murray NJ, Clemens RS, Phinn SR, Possingham HP, Fuller RA. Tracking the rapid loss of tidal wetlands in the Yellow Sea. Front Ecol Environ. 2014;12(5):26772. https://doi.org/10.1890/130260

Newton A, Icely J, Cristina S, Perillo GME, Turner RE, Ashan D, et al. Anthropogenic, direct pressures on coastal wetlands. Front Ecol Evol. 2020;8: 144 Frontiers Media S.A. https://doi.org/10.3389/fevo.2020.00144.

Ogle DH, Wheeler P, Dinno A. FSA: Fisheries Stock Analysis; 2021.

Oksanen J, Guillaume FB, Michael F, Roeland K, Pierre L, Dan M, et al. Package ' vegan '; 2020.

Olff H, De Leeuw J, Bakker JP, Platerink RJ, van Wijnen HJ. Vegetation succession and herbivory in a salt marsh: changes induced by sea level rise and silt deposition along an elevational gradient. J Ecol. 1997;Vol. 85:799-814. https://doi.org/10.2307/2960603.

Parida AK, Das AB. Salt tolerance and salinity effects on plants: a review. Ecotoxicol Environ Saf. 2005;60(3):324-49. https://doi.org/10.1016/j.ecoenv.2 004.06.010.

Pebesma EJ. Multivariable geostatistics in S: the gstat package. Comput GeoSci. 2004;30(7):683-91. https://doi.org/10.1016/j.cageo.2004.03.012.

Santelmann MV, Boisjolie BA, Flitcroft R, Gomez M. Relationships between salt marsh vegetation and surface elevation in Coos Bay Estuary, Oregon. Northwest Sci. 2019;93(2):137-54. https://doi.org/10.3955/046.093.0205.

Silvestri S, Defina A, Marani M. Tidal regime, salinity and salt marsh plant zonation. Estuarine, Coastal and Shelf Science. 2005;62(1-2):119-30. https:// doi.org/10.1016/j.ecss.2004.08.010.

van Regteren M, Amptmeijer D, de Groot AV, Baptist MJ, Elschot K. Where does the salt marsh start? Field-based evidence for the lack of a transitional area between a gradually sloping intertidal flat and salt marsh. Estuarine, Coastal 
and Shelf Science. 2020;243:106909. https://doi.org/10.1016/j.ecss.2020.1 06909.

Woo HJ. Long-term changes of sediment and topography at the Southern Kanghwa Tidal Flat, West Coast of Korea. J Wetlands Res. 2013;15(4):493-500. https://doi.org/10.17663/jwr.2013.15.4.493.

Zare-Mehrjardi M, Taghizadeh-Mehrjardi R, Akbarzadeh A. Evaluation of geostatistical techniques for mapping spatial distribution of soil PH, salinity and plant cover affected by environmental factors in Southern Iran. Notulae Scientia Biologicae. 2010;2(4):92-103. https://doi.org/10.15835/nsb244997.

\section{Publisher's Note}

Springer Nature remains neutral with regard to jurisdictional claims in published maps and institutional affiliations.

Ready to submit your research? Choose BMC and benefit from:

- fast, convenient online submission

- thorough peer review by experienced researchers in your field

- rapid publication on acceptance

- support for research data, including large and complex data types

- gold Open Access which fosters wider collaboration and increased citations

- maximum visibility for your research: over $100 \mathrm{M}$ website views per year

At BMC, research is always in progress.

Learn more biomedcentral.com/submissions 